\title{
THE EFFECT OF DELAYED TIME OF OSCILLATION IN THE LOGISTIC EQUATION
}

\author{
IVONE LAWRITA ERWANSA, EFENDI, AHMAD IQBAL BAQI \\ Program Studi Matematika, \\ Fakultas Matematika dan Ilmu Pengetahuan Alam, Universitas Andalas, \\ Kampus UNAND Limau Manis Padang, Indonesia, \\ Ivonlawrita@gmail.com
}

\begin{abstract}
Time delay logistic equation is a modification of the logistic equation. The equation logistic delay time can affect the increase and decrease in population. This leads to oscillations in the equation. The purpose of this research is to study the oscillation of the logistic equation with time delays.

Kata Kunci: population dynamics, logistic equation, oscillation, equilibrium.
\end{abstract}

\section{Pendahuluan}

Persamaan logistik adalah persamaan yang menggambarkan pertumbuhan populasi dalam suatu lingkungan dengan mempertimbangkan daya dukung lingkungan terbatas. Dalam kenyataannya, sepanjang waktu pertumbuhan keadaan daya dukung lingkungan dapat berubah. Akibatnya pertumbuhan populasi akan mengalami penundaan. Penundaan tersebut menyebabkan penurunan populasi tetapi kemudian terjadi peningkatan sehingga terjadi osilasi pada pertumbuhan populasi [1].

\section{Model Pertumbuhan Logistik dengan Waktu Tunda}

Persamaan Logistik tidak dapat mendeskripsikan pertumbuhan populasi pada kasus keterlambatan (waktu tunda). Oleh karena itu dikembangkan suatu model pertumbuhan logistik dengan waktu tunda. Dengan mengacu pada persamaan model pertumbuhan logistik, maka mekanisme penundaan waktu untuk pertumbuhan populasi dapat dimodelkan dalam persamaan

$$
\frac{d N(t)}{d t}=r N(t)\left[1-\frac{N(t-\tau)}{K}\right]
$$

di mana $N(t)$ menyatakan jumlah populasi pada waktu $t, r$ menyatakan laju pertumbuhan intrinsik (intrinsic growth rate), $N(t-\tau)$ menyatakan jumlah populasi pada saat terjadinya waktu tunda, $K$ menyatakan daya dukung lingkungan (carrying capacity), dan $\tau$ menyatakan waktu tunda [2].

Untuk menyelesaikan model pertumbuhan logistik dengan waktu tunda, digunakan formulasi waktu diskrit untuk memperoleh solusi numerik. 
Model pertumbuhan logistik diskrit dengan waktu tunda $\tau$ diberikan seperti di bawah ini.

$$
N(t+\Delta t)-N(t)=\Delta t N(t)\left[r-\frac{r}{K} N(t-\tau)\right]
$$

dengan pengukuran dilakukan pada setiap selang waktu $\Delta t$.

Pada bagian ini, diasumsikan penundaan waktu dalam mekanisme pertumbuhan selama satu tahun $(\tau=\Delta t=1)$. Penyederhanaan model untuk proses ini merupakan persamaan logistik diskrit dengan waktu tunda sebagai berikut

$$
N(t+\Delta t)=N(t)\left[1+\left(\Delta t r-\Delta t \frac{r}{K} N(t-\Delta t)\right)\right] .
$$

Persamaan (2.3) disederhanakan maka menghasilkan persamaan

$$
N_{m+1}=N_{m}\left(1+\alpha-\beta N_{m-1}\right)
$$

dengan $\alpha=r \Delta t$ dan $\beta=\frac{r}{K} \Delta t$. Sehingga akan diperoleh kesetimbangan populasi $N_{E}=0$, atau

$$
N_{E}=\frac{\alpha}{\beta}=\frac{r \Delta t}{\frac{r}{K} \Delta t}=K .
$$

\section{Analisis Kesetimbangan Model Pertumbuhan Logistik dengan Waktu Tunda dengan Melakukan Pertubasi di Sekitar titik $N(t)=K$}

Perturbasi di sekitar titik kesetimbangan $N(t)=K$ untuk model logistik diskrit ditulis sebagai berikut.

$$
N_{m}=K+\varepsilon y_{m},\left|\varepsilon y_{m}\right| \leq K,
$$

di mana $\varepsilon y_{m}$ adalah perubahan dari titik kesetimbangan $N(t)=K$. Selanjutnya persamaan (3.2) disubstitusikan ke dalam persamaan (2.4), sehingga menghasilkan

$$
y_{m+1}-y_{m}=\left(-\beta y_{m-1} K\right)-\left(\beta y_{m-1} \varepsilon y_{m}\right) \text {. }
$$

Karena $\varepsilon$ sangat kecil dan $y_{m-1} y_{m} \approx 0$ di titik kesetimbangan, yang berarti $\beta y_{m-1}\left(\varepsilon y_{m}\right)=0$, maka diperoleh persamaan berikut:

$$
y_{m+1}-y_{m}=-\alpha y_{m-1}
$$

dengan $\alpha=\beta K$.

Diasumsikan solusi dari persamaan (3.2) adalah $y_{m}=p^{m}$.

$$
p^{m+1}-p^{m}+\alpha p^{m-1}=0,
$$

Jika tiap suku dibagi dengan $p^{m-1}$, maka diperoleh persamaan kuadrat untuk $p$ sebagai berikut:

$$
p^{2}-p+\alpha=0
$$

sehingga solusi umum dari persamaan (3.2) dapat ditulis

$$
y_{m}=c_{1} p_{1}^{m}+c_{2} p_{2}^{m},
$$


Dari akar-akar $p_{1}$ dan $p_{2}$, diperoleh hasil sebagai berikut

(1) Untuk $0<\alpha<\frac{1}{4}$

Diperoleh akar-akar $p_{1}$ dan $p_{2}$ merupakan bilangan real positif, berbeda dan kurang dari 1 , yaitu $0<p_{1}<1,0<p_{2}<1$ dan $p_{1} \neq p_{2}$. Solusi yang didapatkan tidak terjadi osilasi untuk $0<\alpha<\frac{1}{4}$.

(2) Untuk $\alpha=\frac{1}{4}$

Diperoleh akar-akar real positif yang sama yakni $p_{1}=p_{2}=\frac{1}{2}$. Solusi yang didapatkan tidak terjadi osilasi untuk $\alpha=\frac{1}{2}$.

(3) Untuk $\alpha>\frac{1}{4}$

Diperoleh akar-akar kompleks sekawan yakni $p_{1}=\frac{1+i \sqrt{4 a-1}}{2}$ dan $p_{2}=$ $\frac{1-i \sqrt{4 a-1}}{2}$. Untuk interval $\frac{1}{4}<\alpha<1$, solusi $y_{m}$ berosilasi. Secara umum untuk interval $\frac{1}{4}<\alpha<1$ solusi berosilasi di sekitar titik kesetimbangan dan menuju ke nol.

Selanjutnya akan dianalisis perilaku kesetimbangan di sekitar titik kesetimbangan $N(t)=K$ untuk model logistik kontinu. Perturbasi di sekitar titik kesetimbangan $N(t)=K$ ditulis sebagai berikut

$$
N(t)=K+\varepsilon N_{1}(t),\left|\varepsilon N_{1}(t)\right| \leq K,
$$

di mana $\varepsilon N_{1}(t)$ adalah perubahan dari titik kesetimbangan $N(t)=K$. Selanjutnya persamaan (3.3) disubstitusikan kedalam persamaan (2.1), sehingga menghasilkan

$$
\frac{d N_{1}(t)}{d t}=-r N_{1}(t-\tau)-\frac{r N_{1} \varepsilon N_{1}(t-\tau)}{K} .
$$

Karena $\varepsilon$ sangat kecil dan $N_{1}(t) N_{1}(t-\tau) \approx 0$ di titik kesetimbangan, yang berarti $\frac{r N_{1} \varepsilon N_{1}(t-\tau)}{K}=0$ pada persamaan (3.4), maka diperoleh persamaan berikut:

$$
\frac{d N_{1}(t)}{d t}=-r N_{1}(t-\tau)
$$

Dengan mengasumsikan solusi dari persamaan (3.5) adalah $N_{1}(t)=c e^{\lambda t}$, maka persamaan karakteristik persamaan (3.5) dapat ditentukan dengan mensubstitusi $N_{1}(t)=c e^{\lambda t}$ ke dalam persamaan (3.5), sehingga diperoleh

$$
\lambda+r e^{-\lambda \tau}=0,
$$

dengan $\lambda$ adalah solusi dari Persamaan Karakteristik (3.6).

Selanjutnya $\lambda$ ditulis dalam bentuk bilangan kompleks $\lambda=\mu+i v$ dengan $\mu$ dan $v$ masing-masing merupakan bagian riil dan imajiner dari $\lambda$. Dengan mensubstitusi $\lambda=\mu+i v$ ke persamaan karakteristik (3.6) maka diperoleh

$$
\left(\mu+r e^{-\mu \tau} \cos v \tau\right)+i\left(v-r e^{-\mu \tau} \sin v \tau\right)=0 .
$$

Dengan menyamakan komponen real dan imajiner pada ruas kiri dan kanan maka diperoleh:

$$
\begin{gathered}
\mu+r e^{-\mu \tau} \cos v \tau=0, \\
v-r e^{-\mu \tau} \sin v \tau=0 .
\end{gathered}
$$

Untuk menganalisis kestabilan di titik $N(t)=K$ maka akan dilihat beberapa kasus dari $\tau$ sebagai berikut 
(1) Kasus $\tau=0$ (tidak terjadi penundaan pada proses pertumbuhan populasi) Untuk $\tau=0$ persamaan karakteristik (3.6) menjadi

$$
\lambda+r=0 .
$$

Solusi untuk persamaan (3.10) menjadi $N_{1}(t)=c e^{-\mu t}$. Pada kasus ini dapat disimpulkan tidak terjadi osilasi pada $\tau=0$. Hal ini terjadi karena solusi persamaan adalah eksponensial.

(2) Kasus $\tau>0$ (terjadi penundaan pada proses pertumbuhan populasi)

Berikut akan ditentukan syarat dan kondisi dari $\tau>0$ sehingga $\operatorname{Re} \lambda<0$ agar kesetimbangan di titik $N(t)=K$ stabil. Pada kasus ini dilakukan simulasi untuk $0<\tau<\frac{\pi}{2 r}$, model pertumbuhan logistik dengan waktu tunda yang akan digunakan adalah Persamaan (2.3). Dengan memisalkan $\alpha=0,4 ; \beta=0,002$; $N_{E}=\frac{\alpha}{\beta}=200$; dengan $N_{0}=20$; maka diperoleh jumlah populasi berdasarkan pertumbuhan logistik dengan waktu tunda seperti yang tercantum pada gambar dibawah ini.

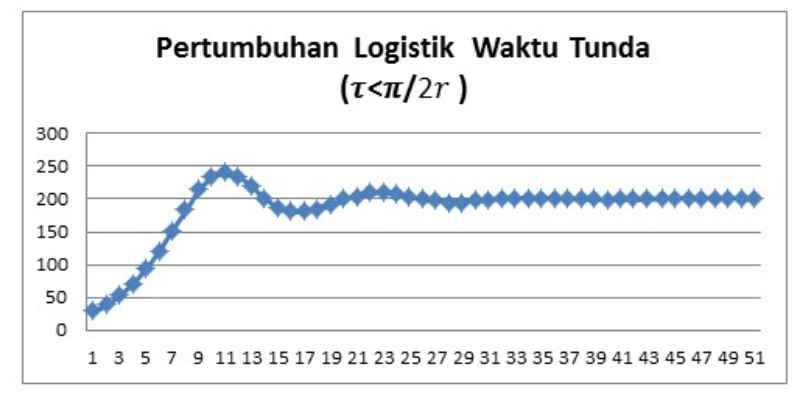

Gambar 1. Pertumbuhan Logistik Waktu Tunda $\tau<\pi / 2 r$

Dari gambar tersebut menunjukkan bahwa pertumbuhan populasi pada awalnya menanjak kemudian berosilasi, dan selanjutnya dalam jangka panjang osilasi semakin kecil mencapai nilai ekuilibrium sehingga keadaan setimbangnya stabil. Untuk selanjutnya dengan waktu tunda yang tidak terbatas jumlah populasi telah mencapai konstan atau stabil. Jadi untuk kasus saat $\tau<\frac{\pi}{2 r}$ populasi menjadi stabil.

(3) Kasus $\tau>\frac{\pi}{2 r}$ (terjadi penundaan pada proses pertumbuhan populasi saat $\frac{\pi}{2 r}$ ) Misalkan $\tau=\tau_{c}+\varepsilon$, maka

$$
\tau=\frac{\pi}{2 r}+\varepsilon, \quad 0<\varepsilon \leq 1,
$$

Untuk $\tau=\frac{\pi}{2 r}$, diketahui bahwa nilai $\mu=0$ dan $v=r$. Untuk $\varepsilon$ yang sangat kecil, $\mu$ dan $v$ berubah menjadi $\mu=\delta$ dan $v=r+\sigma$,

$$
0<\delta \leq 1, \quad 0<\sigma \leq 1
$$


dengan $\delta$ dan $\sigma$ akan ditentukan dengan mensubstitusi Persamaan (3.11) ke persamaan (3.9) dan persamaan (3.9) sehingga diperoleh

$$
\begin{gathered}
\delta=-r \exp \left[-\delta\left(\frac{\pi}{2 r}+\varepsilon\right)\right] \cos \left[(r+\sigma)\left(\frac{\pi}{2 r}+\varepsilon\right)\right] \\
r+\sigma=r \exp \left[-\delta\left(\frac{\pi}{2 r}+\varepsilon\right)\right] \sin \left[(r+\sigma)\left(\frac{\pi}{2 r}+\varepsilon\right)\right]
\end{gathered}
$$

Dari nilai $\delta$ dan $\sigma$ yang telah diperoleh maka solusi dari persamaan (3.5) dapat ditulis sebagai berikut.

$$
N_{1}(t)=\operatorname{Re}\left\{c e^{(u+i v) t}\right\} .
$$

Dengan mengganti nilai $\mu$ dan $v$ yang baru maka

$$
N_{1}(t)=c\left(\exp \left[\frac{r^{2} \varepsilon t}{1+\frac{\pi^{2}}{4}}\right]\right)\left(\cos t\left[r-\frac{r^{2} \varepsilon \pi}{2\left(1+\frac{\pi^{2}}{4}\right)}\right]\right) .
$$

Untuk $\varepsilon>0$, jika semakin besar nilai $\varepsilon$ yang dipakai berarti $\tau$ (waktu tunda) juga semakin besar. Untuk $\tau$ yang semakin besar $\left(\tau>\frac{\pi}{2 r}\right)$ solusi berosilasi semakin besar dan menjauhi titik kesetimbangan. Pada kasus ini dilakukan simulasi untuk $\tau>\frac{\pi}{2 r}$, model pertumbuhan logistik dengan waktu tunda yang akan digunakan adalah Persamaan (2.3). Sebagai contoh penghitungan populasi, dimisalkan $\alpha=1,6 ; \beta=0,008 ; N_{E}=\frac{\alpha}{\beta}=200$; dengan $N_{0}=100$; maka diperoleh jumlah populasi berdasarkan pertumbuhan logistik dengan waktu tunda seperti yang tercantum pada gambar dibawah ini.

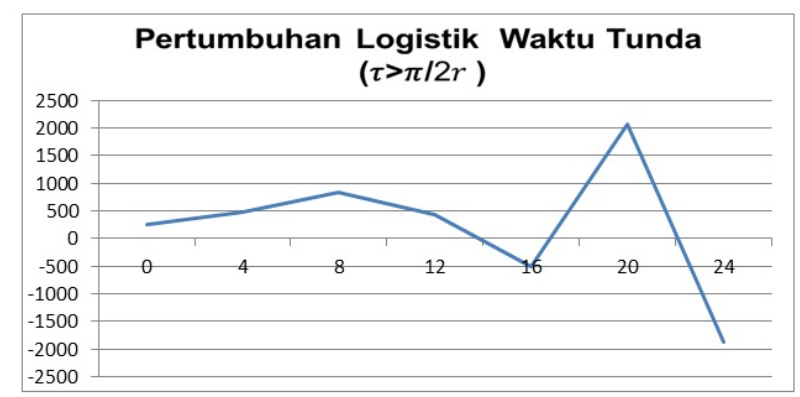

Gambar 2. Pertumbuhan Logistik Waktu Tunda $\tau>\pi / 2 r$

Dari gambar tersebut menunjukkan bahwa pertumbuhan populasi pada awalnya menanjak kemudian berosilasi, dan seiring dengan berjalannya waktu menjauhi nilai ekuilibrium sehingga mengakibatkan keadaan setimbangnya tidak stabil. Jadi untuk kasus $\tau>\frac{\pi}{2 r}$ populasi menjadi tidak stabil.

(4) Kasus $\tau=\frac{\pi}{2 r}$ (terjadi penundaan yang mengakibatkan suatu keadaan setimbang stabil berubah menjadi suatu keadaan setimbang yang tidak stabil).

Dalam hal ini jika waktu tunda $\tau$ meningkat melebihi nilai $\tau=\frac{\pi}{2 r}$, maka keadaan setimbang menjadi tidak stabil. Untuk $\tau=\frac{\pi}{2 r}$ belum bisa ditentukan kestabilannya sehingga perlu pengkajian lebih mendalam. 


\section{Kesimpulan}

Dari pembahasan model pertumbuhan logistik dengan waktu tunda dapat disimpulkan bahwa waktu tunda dapat menyebabkan penurunan populasi tetapi kemudian terjadi peningkatan populasi kembali sehingga terjadi osilasi pada pertumbuhan populasi. Pada saat waktu tunda $\tau<\frac{\pi}{2 r}$ terjadi osilasi terlebih dahulu sebelum mencapai keadaan setimbang, dan saat waktu tunda $\tau>\frac{\pi}{2 r}$ pada awalnya terjadi osilasi yang besar serta kemudian menjauhi titik setimbang.

Untuk kasus waktu tunda $\tau=\frac{\pi}{2 r}$, belum bisa ditentukan kestabilannya sehingga perlu pengkajian yang lebih mendalam serta tersendiri. Dalam hal ini penulis menyarankan mengkaji kasus tersebut pada penelitian berikutnya.

\section{Ucapan Terima kasih}

Penulis mengucapkan terima kasih kepada Bapak Budi Rudianto, Ibu Nova Noliza Bakar, Bapak Dodi Devianto yang telah memberikan masukan dan saran sehingga paper ini dapat diselesaikan dengan baik.

\section{Daftar Pustaka}

[1] Purnomo, D.K. 2000. Model Pertumbuhan Populasi Dengan Memodifikasi Model Pertumbuhan Logistik. Majalah Matematika dan Statistik (1) 1 : 21 -29 .

[2] Timuneno.M , H, Utomo, R.H.S dan Widowati. 2008. Model Pertumbuhan Logistik dengan Waktu Tunda. Jurnal Matematika (11) $1: 43$ - 51 